\title{
FAKTOR-FAKTOR YANG MEMPENGARUHI PEMBERIAN ASI EKSKLUSIF DI POSYANDU BALITA KALINGGA BANYUANYAR SURAKARTA
}

\author{
Nur Rakhmawati ${ }^{1, *}$, Ratih Dwilestari Puji Utami \\ ${ }^{1,2}$ Universitas Kusuma Husada Surakarta \\ ${ }^{1}$ nurrakhmawati_ikmuns@yahoo.co.id*
}

\begin{abstract}
Abstrak
Latar Belakang : Menyusui merupakan salah satu cara yang paling efektif untuk memastikan kesehatan dan kelangsungan hidup anak. Cakupan pemberian ASI eksklusif pada bayi usia 0-6 bulan berfluktuatif. Hasil Survei Demografi dan Kesehatan Indonesia (SDKI) cakupan pemberian ASI eksklusif sebesar 52\% pada tahun 2017. Upaya peningkatan pemberian ASI berperan besar terhadap pencapaian penurunan angka kematian bayi dan menurunnya prevalensi gizi kurang pada anak balita.
\end{abstract}

Tujuan : Penelitian ini bertujuan untuk mendeskripsikan faktor-faktor yang mempengaruhi pemberian ASI Eksklusif.

Metode : Penelitian ini merupakan penelitian analitik observasional dengan pendekatan cross sectional. Pengambilan sampel dilakukan secara consecutive sampling. Populasi penelitian ini adalah ibu yang memiliki bayi usia 6-22 bulan dan berkunjung ke posyandu balita Kalingga Kelurahan Banyuanyar Surakarta yang berjumlah 32 orang. Analisis data yang digunakan adalah analisis data bivariat dengan menggunakan Chi Square dan data multivariat menggunakan regresi logistik ganda.

Hasil : Ada hubungan yang bermakna antara pekerjaan dengan pemberian ASI eksklusif dengan $p$ value sebesar $0,039<0,05$. Ada hubungan yang bermakna antara pendidikan dengan pemberian ASI eksklusif dengan $p$ value $(0,019<0,05)$. Ada hubungan yang bermakna antara dukungan suami dengan pemberian ASI eksklusif dengan $p$ value sebesar $0,028<0,05$. Tidak ada hubungan yang bermakna antara sosial budaya dengan pemberian ASI eksklusif dengan $p$ value sebesar 0,310 >0,05. Faktor yang paling berpengaruh adalah Pendidikan dengan nilai Odd Ratio sebesar 41,241 berarti bahwa ibu yang mempunyai pendidikan tinggi mempunyai kemungkinan 41,241 kali lebih besar untuk memberikan ASI eksklusif daripada ibu yang berpendidikan rendah. Hasil uji Wald diperoleh $p$ value sebesar $0,019<0,05$.

Simpulan: Faktor yang paling berpengaruh adalah Pendidikan dengan nilai Odd Ratio sebesar 41,241 berarti bahwa ibu yang mempunyai pendidikan tinggi mempunyai kemungkinan 41,241 kali lebih besar untuk memberikan ASI eksklusif daripada ibu yang berpendidikan rendah.

Kata Kunci: Status Pekerjaan; Pendidikan; Dukungan suami; ASI eksklusif 


\title{
FACTORS THAT INFLUENCE ON GIVING EXCLUSIVE BREASTFEEDING IN POSYANDU (INTEGRATED HEALTH SERVICE POST FOR TODDLERS), KALINGGA BANYUANYAR, SURAKARTA
}

\begin{abstract}
Background: Breastfeeding is one of the most effective ways to ensure the health and survival of children. The scope of exclusive breastfeeding for infants aged 0-6 months fluctuates. The results by The Indonesian Demographic and Health Surveyshowed that the coverage of exclusive breastfeeding was 52\% in 2017. Efforts to increase breastfeeding contributed to the achievement of reducing infant mortality and reducing the prevalence of malnutrition in children under five.
\end{abstract}

Objective: This study aims to describe the factors that influenceon giving exclusive breastfeeding.

Method: This study was an observational analytic study using a cross sectional approach. Sampling was done by consecutive sampling with the analysis using multiple logistic regression. The population of this study is mothers who have babies aged 6-22 months and visit the Posyandu for toddlers in Kalingga, Banyuanyar, Surakarta total 32 people. Analysis of the data used is bivariate data analysis using chi square and multivariate data with multiple logistic regression. Results: There is a significant relation between one's occupation and exclusive breastfeeding with a $p$ value of $0.039<0.05$. There is a significant relation between education background with exclusive breastfeeding with p value (0.019 <0.05). There is also a significant relation between husband's support and exclusive breastfeeding with a $p$ value of $0.028<0.05$. There is no significant relation between social culture and exclusive breastfeeding with $p$ value of 0.310> 0.05. The most influential factor is background of education with an Odd Ratio of 41,241 meaning that mothers who have higher education were 41,241 times more likely to give exclusive breastfeeding than mothers with low education. The Wald test results obtained is p value of $0.019<0.05$.

Conclusion: The most influential factor is background of education with an Odd Ratio of 41,241 It means that mothers who have higher education are 41,241 times more likely to give exclusive breastfeeding than mothers with low education.

Keywords: OccupationStatus; Background of Education; Husband's Support; Exclusive breastfeeding

\section{PENDAHULUAN}

Menyusui adalah cara normal memberikan nutrisi pada bayi untuk pertumbuhan dan perkembangan yang sehat. Air Susu Ibu (ASI) merupakan nutrisi alamiah terbaik bagi bayi karena mengandung kebutuhan energi dan zat yang dibutuhkan selama enam bulan pertama kehidupan bayi. Hampir semua ibu dapat menyusui asalkan memiliki informasi yang akurat dan terdapat dukungan dari keluarga, sistem perawatan kesehatan dan masyarakat pada umumnya. Menyusui merupakan salah satu cara yang paling efektif untuk memastikan kesehatan dan kelangsungan hidup anak (WHO, 2014). Berdasarkan Peraturan 
Pemerintah Nomor 33 Tahun 2012 tentang Pemberian Air Susu Ibu Eksklusif, air susu ibu atau disingkat ASI adalah cairan hasil sekresi kelenjar payudara ibu. ASI eksklusif adalah ASI yang diberikan kepada bayi sejak dilahirkan selama enam bulan tanpa menambahkan dan/atau mengganti dengan makanan atau minuman lain (Infodatin, 2018).

Cakupan pemberian ASI eksklusif pada bayi usia 0-6 bulan berfluktuatif. Hasil Survei Demografi dan Kesehatan Indonesia (SDKI, 2017), cakupan ASI sebesar 32\% dan menunjukkan kenaikan yaitu menjadi 52\% pada tahun 2017. Berdasarkan laporan Dinas Kesehatan Provinsi, cakupan pemberian ASI eksklusif 0-6 bulan secara nasional pada tahun 2013 adalah 54,3\% (Kementrian Kesehatan RI, 2013) dan meningkat menjadi 37,3\%. Pemberian ASI parsial sebanyak 9,3\% dan ASI predoniman adalah sebanyak 3,3\% (Infodatin, 2018).

Upaya peningkatan pemberian ASI berperan sangat besar terhadap angka kematian bayi dan penurunan prevalensi gizi kurang pada anak balita dan dapat menurunkan angka kesakitan pada balita. Pemberian ASI dapat menurunkan risiko penyakit infeksi akut seperti diare, pneumonia, infeksi telinga, haemophilus influenza, meningitis, dan infeksi saluran kemih. Bayi yang tidak diberi ASI akan rentan terhadap penyakit infeksi. Kejadian bayi dan balita menderita penyakit infeksi yang berulang akan mengakibatkan terjadinya balita dengan gizi buruk dan kurus. Berdasarkan hasil Riskesdas 2018, 17,7\% balita mengalami gizi buruk dan gizi kurang, 30,8\% balita sangat pendek dan pendek, 10,2\% balita sangat kurus dan kurus, dan $8 \%$ balita gemuk (Infodatin, 2018). Angka kematian bayi sudah turun tetapi angka tersebut masih cukup tinggi yaitu pada tahun 2017 angka kematian anak turun dari 40 kematian per 1.000 kelahiran hidup (SDKI, 2017) menjadi 32 kematian per 1.000 kelahiran hidup pada tahun 2017 (Kementrian Pemberdayaan Perempuan dan Perlindungan Anak (KPPPA), 2017).

World Health Organization (WHO) dan United Nations Childrens Fund (UNICEF) merekomendasikan agar ibu menyusui bayinya saat satu jam pertama setelah melahirkan dan melanjutkan hingga usia 6 bulan pertama kehidupan bayi. Pengenalan makanan pelengkap dengan nutrisi yang memadai dan aman diberikan saat bayi memasuki usia 6 bulan dengan terus menyusui sampai 2 tahun atau lebih (WHO, 2016). Setiap anak disusui dalam waktu satu jam setelah melahirkan, hanya diberikan ASI saja selama enam bulan pertama kehidupan, dan ibu terus menyusui sampai usia anak dua tahun, maka sekitar 800.000 jiwa anak akan diselamatkan setiap tahun. Berdasarkan data global, kurang dari $40 \%$ bayi di bawah usia enam bulan mendapatkan ASI eksklusif. Konseling menyusui yang memadai dan dukungan yang diberikan sangat penting bagi ibu dan keluarga untuk memulai dan mempertahankan praktek pemberian ASI secara efektif.

Menurut Habiba, 2016 putusnya pemberian ASI eksklusif dikarenakan beberapa hal sebagai berikut, yaitu: pengetahuan mengenai kandungan zat yang terdapat dalam ASI, adanya anggapan bahwa ASI tidak dapat mencukupi kebutuhan bayi, ibu yang bekerja yang tempat kerjanya tidak memiliki fasilitas untuk menyimpan ASI perah maupun yang tidak memfasilitasi untuk aturan bagi pekerja untuk memerah ASI, serta kurangnya dukungan keluarga untuk menyusui anaknya secara eksklusif. 
Fenomena yang terjadi saat ini adalah berdasarkan studi pendahuluan, tidak semua ibu menyusui dapat memberikan ASI secara eksklusif sehingga menyebabkan angka kematian bayi meningkat dan menurunnya prevalensi gizi kurang pada anak balita.

Berdasarkan latar belakang di atas, penulis tertarik untuk melakukan penelitian tentang "Faktor-Faktor Yang Mempengaruhi Pemberian ASI Eksklusif Di Posyandu Balita Kalingga Banyuanyar Surakarta.”

\section{METODE}

Penelitian ini merupakan penelitian analitik observasional dengan pendekatan cross sectional. Populasi penelitian ini adalah ibu yang memiliki bayi usia 6-22 bulan dan berkunjung ke posyandu balita Kalingga Kelurahan Banyuanyar, Surakarta. Subyek penelitian ini ibu yang memiliki bayi usia 6-22 bulan dan berkunjung ke posyandu balita Kalingga Kelurahan Banyuanyar, Surakarta yang berjumlah 32 orang.

Pada penelitian ini menggunakan alat pengumpul data berupa kuesioner. Analisis data yang digunakan adalah analisis data bivariat dengan menggunakan Chi Square dan data multivariat menggunakan regresi logistik ganda.

HASIL DAN PEMBAHASAN

Tabel 1. Distribusi Frekwensi Karakteristik Responden Berdasarkan Pekerjaan

\begin{tabular}{ccc}
\hline Pekerjaan & Jumlah & Persentase (\%) \\
\hline Bekerja & 15 & 46.9 \\
Tidak Bekerja & 17 & 53.1 \\
Jumlah & 32 & 100 \\
\hline
\end{tabular}

Berdasarkan tabel 1 menunjukkan bahwa mayoritas responden adalah tidak bekerja yaitu sebanyak 17 responden $(53,1 \%)$.

Tabel 2. Distribusi Frekwensi Karakteristik Responden Berdasarkan Pendidikan

\begin{tabular}{ccc}
\hline Pendidikan & Jumlah & Persentase (\%) \\
\hline Rendah & 14 & 43,8 \\
Tinggi & 18 & 56,3 \\
Jumlah & 32 & 100 \\
\hline
\end{tabular}

Berdasarkan tabel 2 menunjukkan bahwa mayoritas responden mempunyai pendidikan tinggi yaitu sebanyak 18 responden $(56,3 \%)$.

Tabel 3. Distribusi Frekwensi Karakteristik Responden Berdasarkan Dukungan Suami

\begin{tabular}{ccc}
\hline Dukungan Suami & Jumlah & Persentase (\%) \\
\hline Tidak mendukung & 13 & 40,6 \\
Mendukung & 19 & 59,4 \\
Jumlah & 32 & 100 \\
\hline
\end{tabular}


Berdasarkan tabel 3 menunjukkan bahwa mayoritas responden mendapatkan dukungan suami yaitu sebanyak 19 responden $(59,4 \%)$.

Tabel 4. Distribusi Frekwensi Karakteristik Responden Berdasarkan Sosial

\begin{tabular}{ccc}
\multicolumn{3}{c}{ Budaya } \\
\hline Sosial Budaya & Jumlah & Persentase (\%) \\
\hline Kurang & 13 & 40.6 \\
Baik & 19 & 59.4 \\
Jumlah & 32 & 100 \\
\hline
\end{tabular}

Berdasarkan tabel 4 menunjukkan bahwa mayoritas responden mempunyai sosial budaya yang baik yaitu sebanyak 19 responden $(59,4 \%)$.

Tabel 5. Distribusi Frekwensi Karakteristik Responden Berdasarkan Pemberian

\begin{tabular}{ccc} 
& ASI Eksklusif \\
\hline Pemberian ASI Eksklusif & Jumlah & Persentase (\%) \\
\hline Non ASI eksklusif & 12 & 37.5 \\
ASI eksklusif & 20 & 62.5 \\
Jumlah & 32 & 100 \\
\hline
\end{tabular}

Berdasarkan tabel 5 hasil penelitian menunjukkan bahwa mayoritas responden memberikan ASI eksklusif pada balitanya yaitu sebanyak 20 responden $(62,5 \%)$.

Tabel 6. Hubungan pekerjaan dengan pemberian ASI eksklusif

\begin{tabular}{|c|c|c|c|c|c|c|c|}
\hline \multirow{3}{*}{ Pekerjaan } & \multicolumn{4}{|c|}{ Pemberian ASI Eksklusif } & \multirow{2}{*}{\multicolumn{2}{|c|}{ Total }} & \multirow{3}{*}{$\begin{array}{l}\mathbf{X}_{2} \\
(\mathbf{p})\end{array}$} \\
\hline & \multicolumn{2}{|c|}{ Non ASI Eksklusif } & \multicolumn{2}{|c|}{ ASI Eksklusif } & & & \\
\hline & $\mathbf{F}$ & $\%$ & $\mathbf{F}$ & $\%$ & $\mathbf{F}$ & $\%$ & \\
\hline Bekerja & 9 & 28.1 & 6 & 18.8 & 15 & 46.9 & \multirow{3}{*}{$\begin{array}{c}6,099 \\
(0,014)\end{array}$} \\
\hline Tidak Bekerja & 3 & 9.4 & 14 & 43.7 & 17 & 53.1 & \\
\hline Total & 12 & 37.5 & 20 & 62.5 & 32 & 100 & \\
\hline
\end{tabular}

Tabel 6 diperoleh nilai chi square $X^{2} 6,099>X^{2}$ tabel $(3,841)$ dan dengan $p$ value $0,014<0,05)$ hal itu berarti bahwa ada hubungan pekerjaan dengan pemberian ASI eksklusif di Posyandu Balita Kalingga Kelurahan Banyuanyar Surakarta.

Tabel 7. Hubungan pendidikan dengan pemberian ASI eksklusif

\begin{tabular}{|c|c|c|c|c|c|c|c|}
\hline \multirow{3}{*}{ Pendidikan } & \multicolumn{4}{|c|}{ Pemberian ASI Eksklusif } & \multirow{2}{*}{\multicolumn{2}{|c|}{ Total }} & \multirow{3}{*}{$\begin{array}{l}\mathbf{X}_{2} \\
(\mathbf{p})\end{array}$} \\
\hline & \multicolumn{2}{|c|}{ Non ASI Eksklusif } & \multicolumn{2}{|c|}{ ASI Eksklusif } & & & \\
\hline & $\mathbf{F}$ & $\%$ & $\mathbf{F}$ & $\%$ & $\mathbf{F}$ & $\%$ & \\
\hline Rendah & 10 & 31.3 & 4 & 12.4 & 14 & 43.7 & \multirow{3}{*}{$\begin{array}{l}12,224 \\
(0,000)\end{array}$} \\
\hline Tinggi & 2 & 6.3 & 16 & 50.0 & 18 & 56.3 & \\
\hline Total & 12 & 37.5 & 20 & 62.6 & 32 & 100. & \\
\hline
\end{tabular}

Berdasarkan tabel 7 diperoleh nilai nilai chi square $X^{2} 12,224>X^{2}$ tabel $(3,841)$ dan dengan $\mathrm{p}$ value $(0,000<0,05)$ hal itu berarti bahwa ada hubungan pendidikan 
dengan pemberian ASI eksklusif di Posyandu Balita Kalingga Kelurahan Banyuanyar Surakarta.

Tabel 8. Hubungan dukungan suami dengan pemberian ASI eksklusif

\begin{tabular}{|c|c|c|c|c|c|c|c|}
\hline \multirow{3}{*}{$\begin{array}{c}\text { Dukungan } \\
\text { Suami }\end{array}$} & \multicolumn{4}{|c|}{ Pemberian ASI Eksklusif } & \multirow{2}{*}{\multicolumn{2}{|c|}{ Total }} & \multirow{3}{*}{$\begin{array}{l}\mathbf{X}_{2} \\
(\mathbf{p})\end{array}$} \\
\hline & \multicolumn{2}{|c|}{ Non ASI Eksklusif } & \multicolumn{2}{|c|}{ ASI Eksklusif } & & & \\
\hline & $\mathbf{F}$ & $\%$ & $\mathbf{F}$ & $\%$ & $\mathbf{F}$ & $\%$ & \\
\hline Tidak & 9 & 28.1 & 4 & 12.5 & 13 & 40.6 & \multirow{3}{*}{$\begin{array}{c}9,406 \\
(0,002)\end{array}$} \\
\hline Mendukung & 3 & 9.4 & 16 & 50.0 & 19 & 59.4 & \\
\hline Total & 12 & 37.5 & 20 & 62.5 & 32 & 100 & \\
\hline
\end{tabular}

Berdasarkan tabel 7 diperoleh nilai chi square $X^{2}$ hitung sebesar 9,406 $>X^{2}$ tabel $(3,841)$ dan dengan $p$ value $(0,000<0,05)$ hal itu berarti bahwa ada hubungan dukungan suami dengan pemberian ASI eksklusif di Posyandu Balita Kalingga Kelurahan Banyuanyar Surakarta.

Tabel 9. Hubungan sosial budaya dengan pemberian ASI eksklusif

\begin{tabular}{|c|c|c|c|c|c|c|c|}
\hline \multirow{3}{*}{$\begin{array}{c}\text { Sosial } \\
\text { Budaya }\end{array}$} & \multicolumn{4}{|c|}{ Pemberian ASI Eksklusif } & \multirow{2}{*}{\multicolumn{2}{|c|}{ Total }} & \multirow{3}{*}{$\begin{array}{l}\mathbf{X}_{2} \\
(\mathbf{p})\end{array}$} \\
\hline & \multicolumn{2}{|c|}{ Non ASI Eksklusif } & \multicolumn{2}{|c|}{ ASI Eksklusif } & & & \\
\hline & $\mathbf{F}$ & $\%$ & $\mathbf{F}$ & $\%$ & $\mathbf{F}$ & $\%$ & \\
\hline Kurang & 6 & 18.7 & 7 & 21.9 & 13 & 40.6 & \multirow{3}{*}{$\begin{array}{r}0,700 \\
(0,403)\end{array}$} \\
\hline Baik & 6 & 18.8 & 13 & 40.6 & 19 & 59.4 & \\
\hline Total & 12 & 37.5 & 20 & 62.5 & 32 & 100 & \\
\hline
\end{tabular}

Berdasarkan tabel 7 diperoleh nilai chi square $X^{2}$ hitung sebesar $9,700<X^{2}$ tabel $(3,841)$ dan dengan $p$ value $(0,403>0,05)$ hal itu berarti bahwa tidak ada hubungan sosial budaya dengan pemberian ASI eksklusif di Posyandu Balita Kalingga Kelurahan Banyuanyar Surakarta.

Tabel 10. Hubungan pekerjaan, pendidikan, dukungan suami dan sosial budaya dengan pemberian ASI eksklusi

\begin{tabular}{lcccc}
\hline \multirow{2}{*}{ Variabel } & Exp (B) & \multicolumn{2}{c}{ CI 95\% } & p Uji \\
\cline { 3 - 4 } & $(\mathbf{O R})$ & Batas bawah & Batas atas & Wald \\
\hline Pekerjaan & 29.844 & 1.186 & 750.748 & .039 \\
Pendidikan & 41.241 & 1.837 & 925.676 & .019 \\
Dukungan Suami & 29.509 & 1.436 & 606.382 & .028 \\
Sosial Budaya & 4.446 & .250 & 78.993 & .310 \\
N observasi & 32 & & & \\
-2 log likelihood & 14,62 & & & \\
Nagelkerke R ${ }^{2}$ & $79,0 \%$ & & & \\
\hline
\end{tabular}

a. Hubungan pekerjaan dengan pemberian ASI eksklusif

Nilai OR variabel pekerjaan sebesar 29,844 berarti bahwa ibu yang tidak bekerja mempunyai kemungkinan 29,844 kali lebih besar untuk memberikan ASI eksklusif daripada ibu yang bekerja. Hasil Uji Wald diperoleh $p$ value sebesar $0,039<0,05$ artinya ada hubungan yang bermakna antara pekerjaan dengan 
pemberian ASI eksklusif di Posyandu Balita Kalingga Kelurahan Banyuanyar Surakarta.

b. Hubungan pendidikan dengan pemberian ASI eksklusif

Nilai OR variabel pendidikan sebesar 41,241 berarti bahwa ibu yang mempunyai pendidikan tinggi mempunyai kemungkinan 41,241 kali lebih besar untuk memberikan ASI eksklusif daripada ibu yang berpendidikan rendah. Hasil Uji Wald diperoleh $p$ value sebesar 0,019 < 0,05 artinya ada hubungan yang bermakna antara pendidikan dengan pemberian ASI eksklusif di Posyandu Balita Kalingga Kelurahan Banyuanyar Surakarta.

c. Hubungan dukungan suami dengan pemberian ASI eksklusif

Nilai OR variabel dukungan suami sebesar 29,509 berarti bahwa ibu yang mendapatkan dukungan suami mempunyai kemungkinan 29,509 kali lebih besar untuk memberikan ASI eksklusif daripada ibu yang tidak mendapatkan dukungan suami. Hasil Uji Wald diperoleh $p$ value sebesar $0,028<0,05$ artinya ada hubungan yang bermakna antara dukungan suami dengan pemberian ASI eksklusif di Posyandu Balita Kalingga Kelurahan Banyuanyar Surakarta.

d. Hubungan sosial budaya dengan pemberian ASI eksklusif

Nilai OR variabel sosial budaya sebesar 4,406. Hasil Uji Wald diperoleh $p$ value sebesar $0,310>0,05$ artinya tidak ada hubungan yang bermakna antara sosial budaya dengan pemberian ASI eksklusif di Posyandu Balita Kalingga Kelurahan Banyuanyar Surakarta.

Berdasarkan Tabel 1 dapat dilihat bahwa menurut karakteristik pekerjaan responden, bahwa mayoritas responden adalah tidak bekerja yaitu sebanyak 17 responden $(53,1 \%)$. Hal ini menunjukkan bahwa ibu yang tidak bekerja mempunyai waktu yang luang untuk memberikan ASI eksklusif pada bayinya. Hal ini sesuai pernyataan dari penelitian Purnama (2011) bahwa ibu yang tidak bekerja, tentunya memiliki waktu yang lebih banyak yang dapat dihabiskan bersama anak mereka. Mereka juga dapat melatih dan mendidik anak, sehingga perkembangan bahasa dan prestasi akademik anak lebih baik jika dibandingkan dengan anak ibu bekerja. Mereka yang tetap di rumah memiliki waktu yang lebih banyak sehingga anak mereka lebih baik secara emosional dan secara akademis, waktu kebersamaan yang ada belum tentu selalu lebih baik daripada ibu yang bekerja. Hal ini dikarenakan kebanyakan waktu yang mereka miliki semata-mata untuk membersihkan dan mengurus rumah. Hal tersebut berarti bahwa pada dasarnya pekerjaan bukanlah alasan untuk tidak memberikan ASI secara eksklusif karena ASI bisa diperah dan tetap diberikan kepada bayi walaupun ibu tidak mendampingi bayinya. Menyusui bisa dilakukan sebelum berangkat bekerja. Ibu yang sudah berada di rumah, maka ibu wajib memberikan hak anaknya untuk menyusui dengan air susunya sendiri (Astutik, 2014).

Tabel 2 menunjukkan karakteristik responden berdasarkan pendidikan, bahwa mayoritas responden mempunyai pendidikan tinggi yaitu sebanyak 18 responden $(56,3 \%)$. Seseorang yang memiliki tingkat pendidikan tinggi maka pengetahuan secara siknifikan akan memiliki pengetahuan yang baik. Menurut teori menyatakan bahwa orang yang memiliki pendidikan tinggi akan merespon yang rasional terhadap informasi yang datang dan akan berfikir sejauh mana keuntungan yang akan mereka dapatkan. Seseorang yang memiliki pendidikan 
tinggi akan lebih mudah menerima hal baru sehingga informasi lebih mudah diterima khususnya tentang ASI eksklusif (Notoatmodjo, 2012).

Tabel 3 menunjukkan karakteristik responden dukungan suami bahwa mayoritas responden mendapatkan dukungan suami yaitu sebanyak 19 responden $(59,4 \%)$. Dukungan suami adalah salah satu bentuk interaksi yang didalamnya terdapat hubungan yang salingmemberi dan menerima bantuan yang bersifat nyata yang dilakukan oleh suami terhadap istrinya (Hidayat, 2011). Dukungan suami diharapkan dapat memberikan manfaat atau sebagai pendorong ibu dalam pemberian ASI eksklusif. Dukungan suami merupakan salah satu faktor yang mempengaruhi sikap ibu dalam pemberian ASI eksklusif (Hargi, 2013). Dukungan suami sangat diperlukan untuk tercapainya pemberian ASI eksklusif. Suami harus memberikan kalimat pujian atau pun kata-kata yang dapat memberikan semangat kepada ibu untuk menyusui bayinya. Salah satu dukungan yang bisa diberikan oleh suami kepada ibu menyusui yakni dengan tidak memberikan kritik terhadap bentuk tubuh istri, karena dengan tidak memberikan kritikan maka istri tidak merasa risih dengan bentuk tubuhnya ataupun bentuk payudaranya sehingga kemauan istri untuk memberikan ASI eksklusif tidak berkurang hanya karena disebabkan oleh kritikan yang disampaikan oleh suami (Abidjulu, dkk, 2015).

Tabel 4 menunjukkan karakteristik responden berdasarkan sosial budaya, bahwa mayoritas responden mempunyai sosial budaya yang baik yaitu sebanyak 19 responden $(59,4 \%)$. Hal ini menunjukan bahwa dengan tingkat sosial budaya yang baik akan membuat ibu dapat menentukan pilihan yang terbaik untuk bayinya, dalam hal ini ibu mampu memberikan ASI secara Eksklusif kepada bayinya. Responden yang memiliki sosial budaya yang baik akan mengerti masalah yang dihadapinya sehingga dia akan memiliki langkah yang tepat untuk memecahkan masalahnya. Sosial budaya merupakan hasil dari tingginya pengetahuan seseorang. Pengetahuan yang tinggi akan mempengaruhi seseorang menentukan langkah yang tepat untuk mengambil keputusan dalam dal masalah sosial. Tingkat pendidikan seseorang akan mempengaruhi pengetahuan orang tersebut. Pengetahun yang tinggi maka dia juga memiliki pengetahuan yang tinggi pula (Hidayati, 2013).

Tabel 5 menunjukkan karakteristik responden berdasarkan pemberian ASI eksklusif, bahwa mayoritas responden memberikan ASI eksklusif pada balitanya yaitu sebanyak 20 responden (62,5\%). Pemberian ASI eksklusif adalah bayi hanya diberi ASI saja, tanpa tambahan makanan padat seperti pisang, pepaya, bubur susu, biskuit, bubur nasi, dan tim. Pemberian ASI secara eksklusif ini dianjurkan untuk jangka waktu sampai 6 bulan (Roesli, 2010). Mohanis (2014), menyebutkan bahwa memberikan ASI eksklusif kepada bayi sangat menguntungkan untuk tumbuh kembang bayi, namun masih banyak juga ibu-ibu dengan berbagai alasan tidak memberikan ASI eksklusif pada bayinya, sehingga cakupan pemberian ASI eksklusif tidak tercapai.

Tabel 6 menunjukkan hubungan pekerjaan dengan pemberian ASI eksklusif, bahwa ada hubungan yang bermakna antara pekerjaan dengan pemberian ASI eksklusif di Posyandu Balita Kalingga Kelurahan Banyuanyar Surakarta dengan $p$ value sebesar $0,039<0,05$. Hasil ini mendukung penelitian 
Mohanis (2014) yang menyatakan bahwa ada hubungan antara status pekerjaan dengan pemberian ASI eksklusif. Bahriyah, dkk (2017) dalam penelitiannya juga bahwa ada hubungan yang bermakna antara pekerjaan ibu terhadap pemberian ASI eksklusif pada bayi. Nilai Odd Ratio variabel pekerjaan sebesar 29,844 berarti bahwa ibu yang tidak bekerja mempunyai kemungkinan 29,844 kali lebih besar untuk memberikan ASI eksklusif daripada ibu yang bekerja, dimana kecenderungan ibu-ibu tidak memberikan ASI eksklusif dikarenakan banyaknya ibu-ibu yang bekerja (Wenas, 2012). Hal ini juga terjadi dikarenakan bagi pekerja wanita yang melahirkan, memberikan ASI eksklusif merupakan suatu dilema, karena masa cuti terlalu singkat dibandingkan masa menyusui, sehingga mereka akan memberikan susu formula sebagai pengganti ASI eksklusif. Menurut Mohanis (2014), hal ini juga terjadi karena kurangnya informasi tentang manajemen laktasi bagi ibu-ibu yang bekerja.

Tabel 7 menunjukkan hubungan pendidikan dengan pemberian ASI eksklusif, bahwa ada hubungan yang bermakna antara pendidikan dengan pemberian ASI eksklusif di Posyandu Balita Kalingga Kelurahan Banyuanyar Surakarta dengan $p$ value $(0,019<0,05)$. Hasil penelitian ini mendukung penelitian Okawary (2015) bahwa semakin tinggi pendidikan ibu semakin banyak ibu yang memberikan ASI eksklusif hal ini dikarenakan ibu yang berpendidikan tinggi memiliki rasa ingin tahu yang lebih tinggi terhadap tumbuh kembang bayinya. Dukungan keluarga juga merupakan faktor pendorong ibu untuk memberikan ASI eksklusif kepada bayinya. Rahayu dan Apriningrum (2014) dalam penelitiannya menyatakan bahwa semakin tinggi tingkat pendidikan ibu maka semakin baik pula motivasi ibu untuk memberikan ASI eksklusif kepada bayinya, semakin tinggi tingkat pendidikan perempuan maka semakin tinggi pula pemanfaatan upaya kesehatan sehingga tingkat kematian bayi akan semakin rendah. Nilai Odd Ratio variabel pendidikan sebesar 41,241 berarti bahwa ibu yang mempunyai pendidikan tinggi mempunyai kemungkinan 41,241 kali lebih besar untuk memberikan ASI eksklusif daripada ibu yang berpendidikan rendah. Hal ini karena pendidikan berhubungan dengan tingkat pengetahuan seseorang, dimana semakin tinggi pendidikan seseorang maka akan semakin mempunyai pengetahuan yang baik tentang pentingnya ASI eksklusif. Hal ini sesuai dengan penelitian yang dilakukan oleh Mekuria \& Edris (2015) yang juga menyatakan bahwa terdapat hubungan yang signifikan pengetahuan dengan ASI eksklusif di mana pada ibu dengan pengetahuan yang baik berpeluang 2,6 kali lebih mungkin untuk memberikan ASI eksklusif. Permata (2014) juga menyatakan bahwa ibu dengan pengetahuan tinggi tentang ASI eksklusif memiliki peluang untuk memberikan ASI eksklusif sebesar 20,8 kali dibandingkan ibu yang berpengetahuan rendah.

Tabel 8 menunjukkan hubungan dukungan suami dengan pemberian ASI eksklusif, bahwa ada hubungan yang bermakna antara dukungan suami dengan pemberian ASI eksklusif di Posyandu Balita Kalingga Kelurahan Banyuanyar Surakarta dengan $p$ value sebesar $0,028<0,05$. Hasil ini mendukung penelitian terdahulu dari Abidjulu, dkk (2015) dengan hasil bahwa terdapat hubungan antara dukungan suami dengan kemauan ibu memberikan ASI eksklusif. Haryono \& Setianingsih (2014) menyatakan bahwa dukungan dari lingkungan keluarga 
termasuk suami, orangtua atau saudara lainnya sangat menentukan keberhasilan menyusui. Seorang ibu yang mendapatkan dukungan dari suami dan anggota keluarga lainnya akan meningkatkan pemberian ASI kepada bayinya. Sebaliknya dukungan yang kurang maka pemberian ASI menurun. Nilai Odd Ratio variabel dukungan suami sebesar 29,509 berarti bahwa ibu yang mendapatkan dukungan suami mempunyai kemungkinan 29,509 kali lebih besar untuk memberikan ASI eksklusif daripada ibu yang tidak mendapatkan dukungan suami.

Tabel 9 menunjukkan hubungan sosial budaya dengan pemberian ASI eksklusif, bahwa tidak ada hubungan yang bermakna antara sosial budaya dengan pemberian ASI eksklusif di Posyandu Balita Kalingga Kelurahan Banyuanyar Surakarta dengan $p$ value sebesar 0,310 >0,05. Permasalahan utama faktor sosial budaya dalam pemberian ASI ekslusif dalam penelitian ini adalah masih adanya kurang kesadaran akan pentingnya ASI (Judarwanto, 2011). Salah satu kendala dalam pemberian ASI eksklusif di Posyandu Balita Kalingga Kelurahan Banyuanyar Surakarta adalah masih terdapatnya pemberian makanan prelakteal yang diberikan oleh ibu. Hal ini sesuai dengan pernyataan dari Johan dan Liyold (2016) bahwa pemberian makanan prelakteal sejak dini merupakan kebiasaan keluarga dan masyarakat turun temurun sambil menunggu ASI keluar, mereka beranggapan dengan memberi makanan sejak dini bayi tidak rewel, tidak cepat lapar, dan pertumbuhan bayi lebih cepat. Ibu yang baru melahirkan lebih percaya pada kebiasaan keluarga/orang tuanya yang dilakukan turun temurun daripada mengaplikasikan informasi dari petugas kesehatan. Pelanggaran pemberian ASI banyak terjadi di berbagai bidang kehidupan, mulai pelanggaran di rumah tangga dimana tanpa disadari bisa dilakukan oleh ibu, ayah, kakek, atau nenek. Perilaku negatif yang sering terjadi pada ibu kurang percaya diri ketika bayi menangis karena tidak mempunyai motivasi dan keinginan yang kuat untuk memberikan ASI. Tidak mau repot dengan tetek bengek memompa ASI, mengganggu keindahan tubuhnya, suami tidak mau membantu dan memotivasi isteri. Pengalaman kakek nenek ketika cucu menangis mendesak ibu untuk memberikan makanan tambahan pada bayinya. Institusi yang tidak mendukung dimana di kantor tempat bekerja tidak ada upaya untuk menyediakan tempat menyusui/memompa ASI. Petugas kesehatan kadang secara tidak sadar mendekorasi tempat praktek dengan berbagai kaleng atau poster susu formula tertentu (Rhokliana, dkk, 2011).

\section{SIMPULAN}

Karakteristik pekerjaan responden mayoritas adalah tidak bekerja. Mayoritas responden mempunyai pendidikan tinggi. Mayoritas responden mendapatkan dukungan suami. Mayoritas responden mempunyai sosial budaya yang baik. Mayoritas responden memberikan ASI eksklusif pada balitanya. Ada hubungan yang bermakna antara pekerjaan dengan pemberian ASI eksklusif. Ada hubungan yang bermakna antara pendidikan dengan pemberian ASI eksklusif. Ada hubungan yang bermakna antara dukungan suami dengan pemberian ASI eksklusif. Tidak ada hubungan yang bermakna antara sosial budaya dengan pemberian ASI eksklusif. Faktor yang paling berpengaruh adalah pendidikan, berarti bahwa ibu yang mempunyai pendidikan tinggi mempunyai kemungkinan 
41,241 kali lebih besar untuk memberikan ASI eksklusif daripada ibu yang berpendidikan rendah.

\section{SARAN}

Bagi ibu menyusui hendaknya ibu lebih meningkatkan pengetahuan dan kesadaran tentang pentingnya memberikan ASI eksklusif yang sangat bermanfaat bagi bayi dan ibu. Bagi Keluarga (Suami) perlunya dukungan keluarga (suami) agar ibu memberikan ASI secara ekslusif pada bayinya sampai usia 6 bulan. Bagi petugas kesehatan hendaknya dapat memberikan konseling ataupun pendidikan kesehatan untuk meningkatkan pengetahuan tentang pemberian ASI eksklusif sekaligus memahami sosial budaya atau kebiasaan dan kepercayaan yang ada dalam masyarakat tersebut sehingga dapat membantu terlaksananya pemberian ASI secara ekslusif pada bayi.

\section{DAFTAR PUSTAKA}

Abidjulu, F.R, Hutagaol, E, Kundre, R (2015). Dukungan Suami Dengan Kemauan Ibu Memberikan Asi Eksklusif Di Puskesmas Tuminting Kecamatan Tuminting. Jurnal diakses tanggal 2 Februari 2018.

Astutik., R.Y (2014). Payudara dan Laktasi. Jakarta: Salemba Medika, pp. 12-3.

Bahriyah, F., Putri, M., Jaelani, AK (2017). Hubungan Pekerjaan Ibu Terhadap Pemberian ASI Eksklusif pada Bayi. Journal Endurance. 2 (2), hal. 113118.

Habiba, S (2016). Faktor-Faktor Yang Mempengaruhi Pemberian ASI Eksklusif Di Wilayah Kerja Puskesmas Kebak Kramat II Kapubaten Karanganyar Tahun 2016. Skripsi. Semarang: Universitas Negeri Semarang.

Hargi, J.P (2013). Hubungan Dukungan Suami dengan Sikap Ibu dalam Pemberian ASI Eksklusif di Wilayah Kerja Puskesmas Arjasa Kabupaten Jember. Skripsi. Program StudiI lmu Keperawatan Universitas Jember.

Haryono, R., \& Setianingsih, S (2014). Manfaat ASI Eksklusif Untuk Buah Hati Anda.Yogyakarta. Gosyen Publishing.

Hidayat, A.A. A (2011). Pengantar Ilmu Keperawatan Anak Jilid I. Jakarta: Salemba Medika.

Hidayati, H (2013). Hubungan Sosial Budaya dengan KeberhasilanPemberian ASI Eksklusif pada Ibu Menyusui di Posyandu Wilayah Desa Srigading Sanden Bantul Yogyakarta. Naskah Publikasi. Program Studi Bidan Pendidik Jenjang D IV Sekolah Tinggi Ilmu Kesehatan 'Aisyiyah Yogyakarta.

Infodatin (2018). Menyusui Sebagai Dasar Kehidupan. https://www.kemkes.go.id/ download.php?file=download/pusdatin/infodatin/infodatin\%20ASI\%20per \%20halaman\%20-\%2002012018.pdf. diakses tanggal 11 Juni 2020

Judarwanto, W (2011). Perilaku Makan Anak Sekolah. Direktorat Bina Gizi.:1-4.

Johan ,H, Liyod S.S (2016). Hubungan Antara Sosial Budaya Dengan Pemberian Asi Ekslusif Di Puskesmas Mangkupalas Samarinda. Jurnal Kebidanan 
Mutiara Mahakam Volume Iv, Nomor 2, September 2016. Diakses tanggal 2 Februari 2018.

Kementrian Kesehatan RI (2013). Info DATIN Pusat Data dan Informasi Kementrian Kesehatan RI. Available at: http://www.depkes.go.id/resources/download/pusdatin/infodatin/infodatinasi.pdf.

Mekuria, G, Edris, M (2015). Exclusive Breastfeeding and Associated Factors Among Mothers in Debre Markos, Northwest Ethiopia: A Cross-Sectional Study.

Mohanis, W (2014). Peran Petugas Kesehatan dan Status Pekerjaan Ibu dengan Pemberian ASI Eksklusif. Jurnal Kesehatan Masyarakat. Vol 8 No 1, hal 40-45.

Notoatmodjo, S (2012). Promosi Kesehatan dan Perilaku Kesehatan. Jakarta: PT Rineka Cipta.

Rahayu, S., \& Apriningrum, N (2014). Faktor-Faktor Yang Berhubungan Pemberian Asi Eksklusif Pada Karyawati Unsika Tahun 2013. Jurnal Ilmiah Solusi, I(1), 55-63. Jurnal diakses tanggal 2 Februari 2018.

Rhokliana, Aisyah, S., Chandradewi, A (2011). Hubungan Sosial Budaya dengan Pemberian ASI Pada Bayi di Wilayah Kerja Puskesmas Keruak Kabupaten Lombok Timur. Jurnal Kesehatan Prima, Vol 5 No 2, hal 765-777.

Roesli, U (2010). Indonesia Menyusui.Badan Penerbit IDAI. Pp:13-24

SDKI (2017). Survei Demografi Kesehatan Indonesia Tahun 2017, Available at:https://e-koren.bkkbn.go.id/wp-content/uploads/2018/10/Laporan-SDKI2017-WUS.pdf.

Okawary, O (2015). Hubungan Status Pekerjaan Ibu Dengan Pemberian ASI Eksklusif Di Wilayah Kerja Puskesmas Seyegan SlemanYogyakarta. NaskahPublikasi. Sekolah Tinggi Ilmu Kesehatan 'Aisyiyah, Yogyakarta. Diakses diakses tanggal 2 Februari 2018.

Permata (2014). Faktor-Faktor yang Berhubungan dengan Pemberian ASI Eksklusif Oleh Ibu Menyusui yang Bekerja SebagaiTenaga Kesehatan. Diakses diakses tanggal 2 Februari 2018.

Purnama, U (2011). Hubungan Antara Status Ibu Bekerja Atau Ibu Tidakbekerja Dengan Status Gizi Anak Balita Di Kecamatan Medan Tembung. Diakses diakses tanggal 2 Februari 2018.

Wenas, (2012). Hubungan Antara Pengetahuan Dan Pekerjaan Ibu Dengan Pemberian Air Susu Ibu (ASI) Eksklusif Di Wilayah Kerja Puskesmas Remboken Kecamatan Remboken Kabupaten Minahasa. Diakses tanggal 2 Februari 2018.

WHO (2014). Breastfeeding, Available at: http://www.who.int/topics/breastfeeding/

World Health Organization (2016). Pemberian ASI Eksklusif [cited 201620 February]. Availablefrom: www.who.int. 